International Research Journal of Management, IT \& Social Sciences
Available online at https://sloap.org/journals/index.php/irjmis/
Vol. 7 No. 3, May 2020, pages: 83-90
ISSN: 2395-7492
https://doi.org/10.21744/irjmis.v7n3.920

\title{
The Effect of Brand Image and Country of Origin on Consumer Buying Interest: Case Study on Yamaha NMAX Motorcycle in Denpasar City
}

Ni Nyoman Rusmiati

I Gusti Ayu Sugiati ${ }^{b}$

A.A. Sri Purnami ${ }^{\mathrm{c}}$

I Made Suniastha Amerta ${ }^{d}$

Article history:

Submitted: 18 March 2020

Revised: 27 April 2020

Accepted: 09 May 2020

\section{Keywords:}

brand image; consumer behavior; country of origin; intention to buy; purchase intention;

\begin{abstract}
Positive perceptions and consumer trust in a brand will create a good brand image. Therefore the company must be able to create an attractive brand and describe the benefits of the product under the wishes of consumers so that consumers have a positive perception of the brand. Besides, what consumers often use to consider choosing a product is the country of origin of the product. The country of origin is generally considered to be a characteristic of a product. So the purpose of this study was to determine the effect of brand image and country of origin on the purchase intention of Yamaha NMAX motorcycles in Denpasar City. The results showed that: Brand Image and country of origin have a positive and significant influence on the purchase intention of Yamaha NMAX motorcycles in Denpasar City.
\end{abstract}

International research journal of management, IT and social sciences (C) 2020. This is an open access article under the CC BY-NC-ND license (https://creativecommons.org/licenses/by-nc-nd/4.0/).

Corresponding author:

Ni Nyoman Rusmiati,

Faculty of Economics and Business, Warmadewa University, Denpasar, Indonesia.

Email address: rusmiatiwarmadewa@gmail.com

\footnotetext{
${ }^{a}$ Faculty of Economics and Business, Warmadewa University, Denpasar, Indonesia

${ }^{b}$ Faculty of Economics and Business, Warmadewa University, Denpasar, Indonesia

Faculty of Economics and Business, Warmadewa University, Denpasar, Indonesia

${ }^{\mathrm{d}}$ Faculty of Economics and Business, Warmadewa University, Denpasar, Indonesia
} 


\section{Introduction}

At this time the needs of the community for transportation facilities to support their daily activities are increasing. One means of transportation the most widely used by the people of Indonesia is private transportation, which is a motorcycle. One of the motorcycles on the market is the Yamaha NMAX motorcycle that has existed since 2015. Advantages owned by Yamaha NMAX are as a basis for consideration and evaluation of consumers.

The advantages of Yamaha NMAX include: Features Yamaha NMAX, the engine is more resilient than competitors, Dimensions are classified as a large body scooter. The other considerations which are often used by consumers, namely about the country of origin of the product. Before deciding what products to buy, for some consumers will see where the country of origin of the product is, the country of origin is generally considered to be a characteristic of a product.

The objectives of this study are (1) To determine the effect of brand image and country of origin on the purchase intentions of Yamaha NMAX motorcycle consumers in Denpasar City; (2) To find out the effect of brand image on the purchase intention of NMAX motorcycle consumers in Denpasar City; (3) For know the influence of country of origin on the purchase intention of NMAX motorcycle consumers in the city of Denpasar (Lee \& Shin 2010; Balakrishnan et al., 2014; Bian \& Forsythe, 2012).

\section{Literature review}

Consumer behavior

Perilaku consumers describe a study of the various processes involved when individuals or groups choose, buy, which meet their needs and desires. Consumer behavior occurs because it is based on certain motives. Every consumer action is taken to achieve the goal of satisfying a need and or desire (Jaminyasa et al., 2017; Mowen, 2004; Stephen, 2016).

\section{Brand image}

The definition of a brand image according to Kotler \& Keller (2009), is the perception held by consumers when they first hear the slogan that is remembered and embedded in the minds of consumers. Consumers will embrace perceptions and beliefs under the experiences they have felt and summarized in their memories (Cretu \& Brodie, 2007; Michel \& Rieunier, 2012; Chien et al., 2011).

\section{Country of origin}

Country of origin or commonly referred to as the country of origin (COO) is the country where a product originates. $\mathrm{COO}$ itself is a reflection or mental image of a product from a particular country. One of the effects that COOs have on potential customers, that is, often prospective consumers have the perception that certain companies or brands are associated with certain countries (Dinata et al., 2015; Pereira et al., 2005; Godey et al., 2012).

\section{Purchase intention}

According to Sehifman \& Kanuk (2008), expressed interest is one of the psychological aspects of a person and has a considerable influence on behavioral attitudes. According to Kotler \& Keller (2009), buying interest is a consumer behavior that arises in response to objects that indicate the customer's desire to make a purchase. So from some of these definitions, it can be concluded that buying intention is a consumer behavior where this intention arises from within consumers that consumers need a product and shows the desire to make a purchase.

\section{Materials and Methods}

This study uses primary data types obtained by giving questionnaires to the people in Denpasar City. The population is consumers who have made purchases of Yamaha NMAX motorcycle products in Denpasar with an unknown population number (infinite), and the determination of samples using non-probability sampling methods, namely sampling techniques that do not provide the same opportunities for each element or member of the population to be selected as a sample (Rahyuda et al., 2004). The data analysis method used in this research is inferential analysis. Data analysis includes correlation and regression analysis which is useful for finding the effect of one construct on another. However, before the data can be processed for inferential analysis, the data must be free from the classical assumption test (Sugiyono, 2006). 
The hypotheses in this study are: (1) Brand image and country of origin have a positive and significant effect on purchase intentions of Yamaha NMAX motorcycles; (2) Brand image has a positive and significant effect on the purchase intention of NMAX motorcycles in Denpasar City; (3) Country of origin has a positive and significant effect on the purchase intention of Yamaha NMAX motorcycles in Denpasar City.

\section{Results and Discussions}

\subsection{Results}

Multiple linear regression analysis was used to determine the effect of brand image and country of origin on the purchase intention of Yamaha NMAX motorcycles. Multiple linear regression is expressed in terms of multiple linear regression equation (Sugiyono, 2006):

$$
Y=a+b_{1} X 1+b 2 X 2+e i
$$

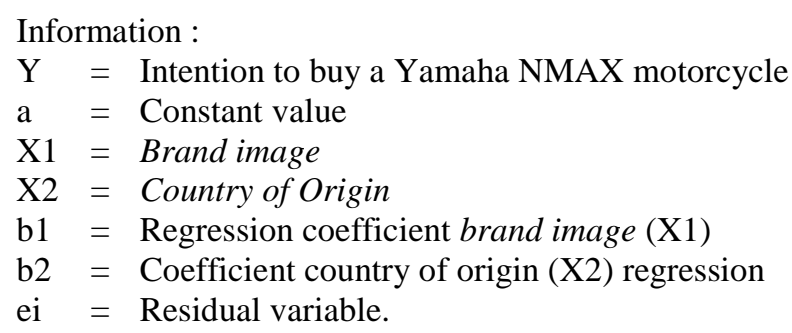

Based on the results of data processing using SPSS 17.0 for windows, the results can be seen in the following Table 1:

Table 1

Results of multiple linear regression analysis

Coefficients $^{\mathbf{a}}$

\begin{tabular}{|c|c|c|c|c|c|}
\hline \multirow[b]{2}{*}{ Model } & \multicolumn{2}{|c|}{$\begin{array}{l}\text { Unstandardized } \\
\text { Coefficients }\end{array}$} & \multirow{2}{*}{$\begin{array}{c}\begin{array}{c}\text { Standardized } \\
\text { Coefficients }\end{array} \\
\text { Beta }\end{array}$} & \multirow[b]{2}{*}{$\mathrm{t}$} & \multirow[b]{2}{*}{ Sig. } \\
\hline & $\mathrm{B}$ & Std. Error & & & \\
\hline $1 \quad$ (Constant) & 7,552 & 2,545 & & 2,968 & .004 \\
\hline $\mathrm{X} 1$ & .427 & .126 & .364 & 3,399 & .001 \\
\hline $\mathrm{X} 2$ & .614 & .192 & 342 & 3,196 & .002 \\
\hline
\end{tabular}

a. Dependent Variable: Y

From the summary of the results of data analysis above, the value of $\mathrm{a}=7.552$ is obtained; $\mathrm{b} 1=0.364 ; \mathrm{b} 2=0.342$; Based on the values a, b1, b2 above, then the multiple linear regression equation is arranged as follows:

$$
\mathrm{Y}=7,552+0,427 \mathrm{X} 1+0,614 \mathrm{X} 2
$$

$\mathrm{a}=7,552$, which means that if the brand image and country of origin are in a constant state, the purchase intention will be 7,552 or the intention to buy a Yamaha NMAX motorcycle in Denpasar City will remain as before.

$\mathrm{b} 1=0,427$, which means that if the brand image increases by one unit, the purchase intention of buying Yamaha NMAX motorbikes in Denpasar City will increase by 0.427 assuming the country of origin variable is fixed.

b2 $=0,614$, which means that if the country of origin increases, by one unit, the intention to buy a Yamaha NMAX motorcycle in Denpasar will increase by 0.614 assuming the variable brand image is in a fixed state.

Rusmiati, N. N., Sugiati, I. G. A., Purnami, A. S., \& Amerta, I. M. S. (2020). The effect of brand image and country of origin on consumer buying interest: case study on Yamaha NMAX motorcycle in Denpasar city. International Research Journal of Management, IT and Social Sciences, 7(3), 83-90. https://doi.org/10.21744/irjmis.v7n3.920 
Statistical Test F (F-test)

This test is used to test the significance of the multiple correlation coefficient or regression coefficient so that it is known whether the simultaneous influence of brand image and country of origin on consumer purchase intentions is real (significant) or only obtained by chance. (Sugiyono, 2006) is formulated as follows:

$$
\text { F-hitung }=\frac{R^{2} /(k-I)}{\left(1-R^{2}\right) /(n-k)}
$$

The statistical test steps are:

a. Determine the hypothesis formulation

In determining the formulation must be adjusted to the sound of the hypothesis

$\mathrm{H} 0: \mathrm{b} 1,2=0$, means there is no positive and significant effect simultaneously brand image and country of origin for consumer purchase intentions.

Hi: b1,2>0, means there is a positive and significant effect simultaneously brand image and country of origin for consumer purchase intentions.

b. Determination of the F-calculated value

The results of data processing with SPSS 17.0 for windows, can be seen in Table 2 as follows.

Table 2

F-Calculated test results

ANOVA $^{\text {b }}$

\begin{tabular}{|ll|r|r|r|r|r|}
\hline Model & & Sum of Squares & Df & Mean Square & F & Sig. \\
\hline 1 & Regression & 168,254 & 2 & 84.127 & 17,549 & $.000 \mathrm{a}$ \\
& Residual & 321,189 & 67 & 4,794 & & \\
& Total & 489,443 & 69 & & & \\
\hline
\end{tabular}

a. Predictors: (Constant), X2, X1

b. Dependent Variable: Y

c. Draw the area of rejection and acceptance Ho

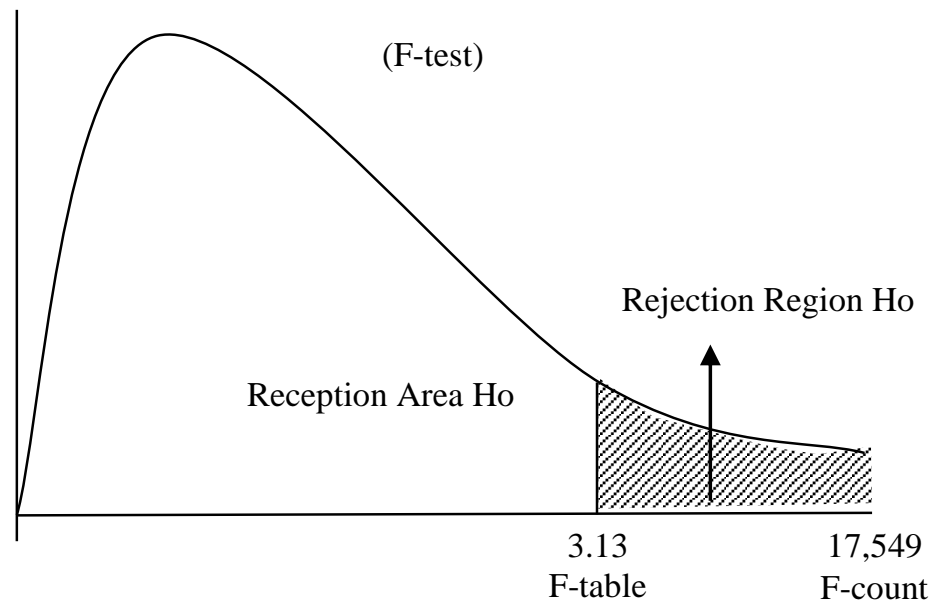

d. Decision

Figure 1. Reception and Rejection Region Ho

The results of calculations with the SPSS program and according to the image of acceptance and rejection of Ho as well as predetermined criteria, the F-calculated value is obtained 17,549 greater than F-table of 3.13 is in the area of rejection of Ho, then Ho is rejected or Hi is accepted, it means that there is indeed a positive and 
significant effect between brand image and country of origin simultaneously on the intention to buy Yamaha NMAX motorbikes in Denpasar and not accidentally.

\section{Statistical Test $t$ (t-test)}

This test is used to test the significance of each regression coefficient, so it is known whether there is an influence individually brand image and country of origin on consumer purchase intentions are real (significant) or only obtained by chance.

Table 3

Test results $\mathrm{t}$

\section{Coefficients $^{\mathrm{a}}$}

\begin{tabular}{|c|c|c|c|c|c|}
\hline \multirow[b]{2}{*}{ Model } & \multicolumn{2}{|c|}{$\begin{array}{l}\text { Unstandardized } \\
\text { Coefficients }\end{array}$} & \multirow{2}{*}{$\begin{array}{c}\begin{array}{c}\text { Standardized } \\
\text { Coefficients }\end{array} \\
\text { Beta }\end{array}$} & \multirow[b]{2}{*}{$\mathrm{t}$} & \multirow[b]{2}{*}{ Sig. } \\
\hline & B & Std. Error & & & \\
\hline $1 \quad$ (Constant) & 7,552 & 2,545 & & 2,968 & .004 \\
\hline $\mathrm{X} 1$ & .427 & .126 & .364 & 3,399 & .001 \\
\hline $\mathrm{X} 2$ & .614 & .192 & 342 & 3,196 & .002 \\
\hline
\end{tabular}

a. Dependent Variable: Y

The results of testing each variable are as follows:

a. Testing the regression coefficient b1

1) Determine the hypothesis formulation

Ho: $\mathrm{b} 1=0$, means there is no significant influence individually brand image on consumer purchase intentions

Hi: b1>0, means there is influence positive and significant individual brand image of consumer purchase intentions.

Distribution $t$ table).

2) Draw the area of acceptance and rejection of Ho

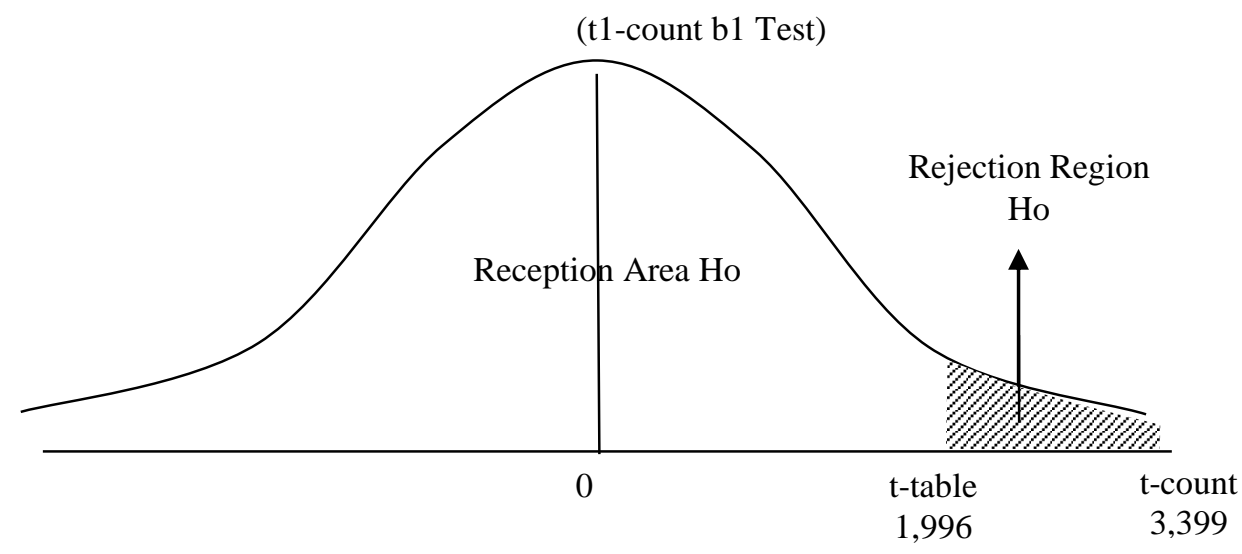

Figure 2. Reception and rejection region Ho

3) Conclusion

According to the calculation results and based on Figure 2, the t-value for the brand image variable is 3,399 greater than t-table $(1,996)$, is in the area of rejection of Ho, which means Ho is rejected and H1 is accepted, which means that the brand image is partial effect significantly on the intention to buy a Yamaha NMAX motorcycle in the city of Denpasar and not accidentally obtained.

Rusmiati, N. N., Sugiati, I. G. A., Purnami, A. S., \& Amerta, I. M. S. (2020). The effect of brand image and country of origin on consumer buying interest: case study on Yamaha NMAX motorcycle in Denpasar city. International Research Journal of Management, IT and Social Sciences, 7(3), 83-90. https://doi.org/10.21744/irjmis.v7n3.920 
b. Testing the regression coefficient b2

1) Determine the hypothesis formulation

Ho: $\mathrm{b} 2=0$, means there is no significant influence individually country of origin on consumer purchase intentions

Hi: b2>0, means there is influence positive and significant individual country of origin on consumer purchase intentions.

2) Draw the area of acceptance and rejection of Ho

(t2-count b2 Test)

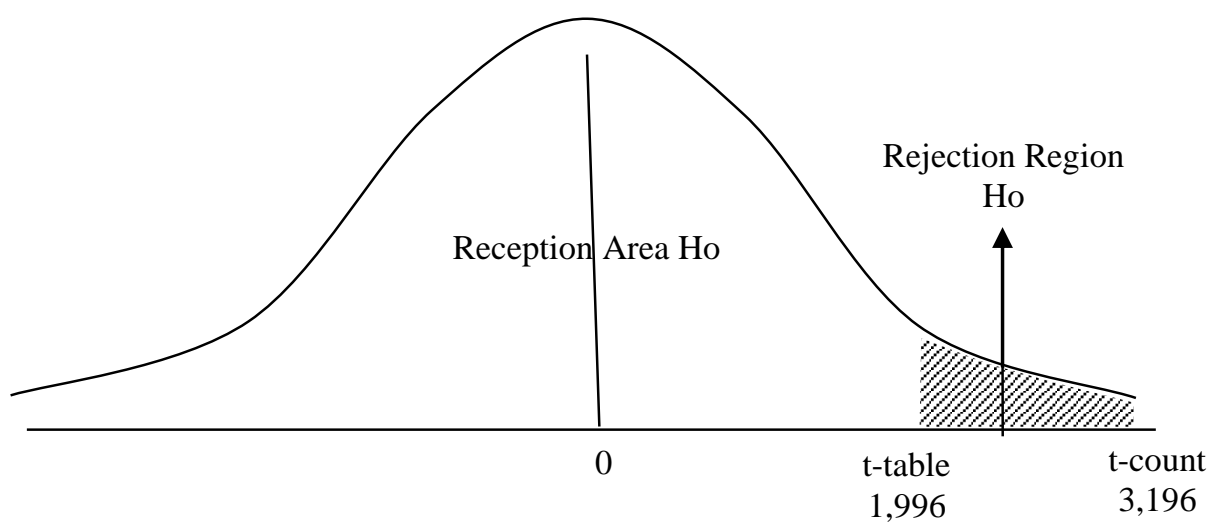

Figure 3. Reception and Rejection Region Ho

3) Conclusion

According to the calculation results and based on Figure 10, the t-count value for the country of origin variable is 3.196 greater than t-table (1.996), is in the area of rejection of Ho, which means Ho is rejected and $\mathrm{H} 1$ is accepted, which means that the country of origin partially significant effect on the intention to buy a Yamaha NMAX motorcycle in Denpasar and not accidentally obtained (Moon et al., 2008; Hajli, 2015; Ueasangkomsate \& Santiteerakul, 2016).

\subsection{Discussion}

1) The influence of brand image on the intention to buy a Yamaha NMAX motorcycle in the city of Denpasar The results found that brand image had a positive and significant influence on the purchasing intentions of Yamaha NMAX motorcycles in Denpasar City in Denpasar City. The results of this study are consistent with research conducted by Rizkia (2015); Wina (2016); and Judge et al. (2017), which found that brand image had a positive and significant influence on consumer purchase intentions.

2) The influence of country of origin on the intention to buy a Yamaha NMAX motorcycle in Denpasar

The results found that product quality had a positive and significant effect on the purchasing intentions of Yamaha NMAX motorcycles in Denpasar City. The results of this study are consistent with research conducted by Rafida (2015); Parlina \& Ramli (2017); and Kusumaningtyas (2017), which found that country of origin had a positive and significant influence on purchasing intentions of Yamaha NMAX motorcycles in Denpasar City.

\section{Conclusion}

From the results of the analysis that has been done, it can be drawn conclusions related to the influence of brand image and country of origin on the purchase intention of Yamaha NMAX motorcycles in Denpasar City are as follows:

1) Brand image and country of origin have a positive and significant influence on the purchase intention of Yamaha NMAX motorcycles in Denpasar City.

2) Brand image has a positive and significant effect on the intention to buy a Yamaha NMAX motorcycle in Denpasar. 
3) The country of Origin has a positive and significant effect on the intention to buy a Yamaha NMAX motorcycle in Denpasar.

Conflict of interest statement

The authors declared that they have no competing interests.

Statement of authorship

The authors have a responsibility for the conception and design of the study. The authors have approved the final article.

Acknowledgments

We are grateful to two anonymous reviewers for their valuable comments on the earlier version of this paper.

Rusmiati, N. N., Sugiati, I. G. A., Purnami, A. S., \& Amerta, I. M. S. (2020). The effect of brand image and country of origin on consumer buying interest: case study on Yamaha NMAX motorcycle in Denpasar city. International Research Journal of Management, IT and Social Sciences, 7(3), 83-90. https://doi.org/10.21744/irjmis.v7n3.920 


\section{References}

Balakrishnan, B. K., Dahnil, M. I., \& Yi, W. J. (2014). The impact of social media marketing medium toward purchase intention and brand loyalty among generation Y. Procedia-Social and Behavioral Sciences, 148, 177-185. https://doi.org/10.1016/j.sbspro.2014.07.032

Bian, Q., \& Forsythe, S. (2012). Purchase intention for luxury brands: A cross cultural comparison. Journal of Business Research, 65(10), 1443-1451. https://doi.org/10.1016/j.jbusres.2011.10.010

Chien, P. M., Cornwell, T. B., \& Pappu, R. (2011). Sponsorship portfolio as a brand-image creation strategy. Journal of Business Research, 64(2), 142-149. https://doi.org/10.1016/j.jbusres.2010.02.010

Cretu, A. E., \& Brodie, R. J. (2007). The influence of brand image and company reputation where manufacturers market to small firms: A customer value perspective. Industrial marketing management, 36(2), 230-240. https://doi.org/10.1016/j.indmarman.2005.08.013

Dinata, Jovita S., Srikandi Kumadji., \& Kadarisman Hidayat. (2015). Country of origin and its Effect on Quality and Interest in BCI (Survey of Prospective Customers Who Are Interested in Buying an iPad in Indonesia) Journal of Business Administration (JAB), 25(1), 1-8.

Godey, B., Pederzoli, D., Aiello, G., Donvito, R., Chan, P., Oh, H., ... \& Weitz, B. (2012). Brand and country-of-origin effect on consumers' decision to purchase luxury products. Journal of Business research, 65(10), 1461-1470. https://doi.org/10.1016/j.jbusres.2011.10.012

Hajli, N. (2015). Social commerce constructs and consumer's intention to buy. International Journal of Information Management, 35(2), 183-191. https://doi.org/10.1016/j.ijinfomgt.2014.12.005

Jaminyasa, I. M., Pulawan, I. M., Martadiani, A. M., \& Amerta, I. M. S. (2017). The marketing mix affect on the consumer buying decision (case study of sausage products at PT. Aroma Denpasar). International Journal of Social Sciences and Humanities, 1(2), 65-74. https://doi.org/10.29332/ijssh.v1n2.44

Judge, T. A., Weiss, H. M., Kammeyer-Mueller, J. D., \& Hulin, C. L. (2017). Job attitudes, job satisfaction, and job affect: A century of continuity and of change. Journal of Applied Psychology, 102(3), 356. https://psycnet.apa.org/doi/10.1037/ap10000181

Katler, P., \& Keller, K.L. (2009). Marketing Management Volume I, Thirteenth Edition. Jakarta: Erlangga

Kusumaningtyas, R., \& Van Gelder, J. W. (2017). Towards responsible and inclusive financing of the palm oil sector (Vol. 175). CIFOR.

Lee, K. H., \& Shin, D. (2010). Consumers' responses to CSR activities: The linkage between increased awareness and purchase intention. Public Relations Review, 36(2), 193-195. https://doi.org/10.1016/j.pubrev.2009.10.014

Michel, G., \& Rieunier, S. (2012). Nonprofit brand image and typicality influences on charitable giving. Journal of Business Research, 65(5), 701-707. https://doi.org/10.1016/j.jbusres.2011.04.002

Moon, J., Chadee, D., \& Tikoo, S. (2008). Culture, product type, and price influences on consumer purchase intention to buy personalized products online. Journal of business research, 61(1), 31-39. https://doi.org/10.1016/j.jbusres.2006.05.012

Mowen, J. C. (2004). Exploring the trait of competitiveness and its consumer behavior consequences. Journal of Consumer Psychology, 14(1-2), 52-63. https://doi.org/10.1207/s15327663jcp1401\&2_7

Parlina, A., \& Ramli, K. (2017). Performance Comparison of Clustering Algorithms on Scientific Publications. Advanced Science Letters, 23(4), 3730-3732.

Pereira, A., Hsu, C. C., \& Kundu, S. K. (2005). Country-of-origin image: measurement and cross-national testing. Journal of Business Research, 58(1), 103-106. https://doi.org/10.1016/S0148-2963(02)00479-4

Rafida, V. (2015). Pengaruh Country Of Origin terhadap Minat Beli dengan Perceived Quality Sebagai Variabel Intervening (Studi pada Pengunjung Artomorro Selluler Kota Madiun). Jurnal Pendidikan Tata Niaga $(J P T N), 3(2)$.

Rahyuda, I. K. I Gst. Wayan Murjana Yasa, dan Ni Nyoman Yuliarmi. 2004. Metodologi Penelitian.

Rizkia (2015). The influence of Brand Image on Microsoft Mobile (Nokia) Consumer Purchase Interest (Survey on Mega Cellular Padjajaran).

Schiffinan, Leon G, and Leslie Lazar. 2008. Consumer Behavior. New Jersey: Prentice Hall.

Stephen, A. T. (2016). The role of digital and social media marketing in consumer behavior. Current Opinion in Psychology, 10, 17-21. https://doi.org/10.1016/j.copsyc.2015.10.016

Sugiyono, D. R. (2006). Statistika untuk penelitian. Bandung: CV. Alfabeta.

Ueasangkomsate, P., \& Santiteerakul, S. (2016). A study of consumers' attitudes and intention to buy organic foods for sustainability. Procedia Environmental Sciences, 34, 423-430. https://doi.org/10.1016/j.proenv.2016.04.037

Wina (2016). Effect of Brand Image with Consumer Purchase Interest in Aqua Bottled Water. 